\title{
日立造船と富岡機械のリファイナー
}

\section{日立造船株式会社 \\ 日立造船富岡機械株式会社 \\ Refiners of Hitachi Zosen Corporation and Hitachi Zosen Tomioka Machinery Co.}

\author{
Hitachi Zosen Corporation \\ Hitachi Zosen Tomioka Machinery Co., Ltd.
}

\begin{abstract}
Hitachi Zosen Corporation manufactures Double Disc Refiners for mechanical pulping under license from Andritz-Sprout-Bauer and handles single refiners of this brand as a part of refining systems. This paper introduces outline of the Double Disc Refiner (DDR) together with its feeding systems, Twin Refiner and Single Disc Refiner (SDR).

On the other hand, Hitachi Zosen Tomioka Machinery Co., Led. manufactures DDR and conical refiners mainly for stock preparation under license from Sulzer Escher Wyss GmbH of Germany. Second half of this paper presents their outlines followed by a literature on effective use of the refining energy written by Dr. Siewert and Mr. Selder of Sulzer Escher Wyss.
\end{abstract}

\begin{abstract}
緒言
日立造船株式会社は TMP など機械パルプ製造用に ダブルディスクリファイナーをアンドリッツ・スプラ ウト・バウアー社との技術提携により製作してきた。 またア社のシングルリファイナーとツインリファイ ナーをシステムに組み込むこともできる。ここに第 1 部として両系統のリファイナーについてその概要をご 紹介したい。また日立造船富岡機械株式会社はスル ザー・エッシャーウイス社との技術提携により主とし て原料調成用ディスクリファイナーとコニカルリファ イナーを製作しているが，これについて第 2 部でご紹 介し，あわせてリファイニング・エネルギーの経済的 な利用についてのエ社論文の全訳をご参考に供する。
\end{abstract}

リファイニング技術 I 45 (11) 43

II 45 (12) 52

III 46 ( 2) 49
一第 1 部一

日立造船／アンドリッツ・スプラウト・バウ アーのメカニカルパルピング用リファイ ナー

日立造船株式会社 プラント計画部

\section{1 まえがき}

当社は1963 年に大昭和製紙蛛白老.場殿へメカ二 カルパルピング用リファイナーの第 1 号機として CGP 用 Hi-D リファイナーを納人し，その後 1969 年 にCE・バウアー社とダブルディスクリファイナー (DDR) の製作・販売の提携を結び，以来約 70 台の DDR を国内外のユーザーに納入している。

そのうち, 当社笑績の最大級のものは装備動力 $11,000 \mathrm{hp}$, ディスク径 56 in である。大型リファイナー

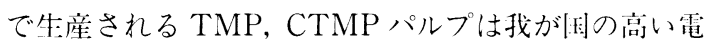
カコストにもかかわらず，すぐれた出質特性により新 聞用紙をはじめ中下級印刷用紙などに使用され, 近年 
その生産量は急速に増加している。また CTMPはケ ミカルパルプに比べ歩留が高いことから，これの代用 として使用され，森林資源の保護の点からも期待され ている。特に最近は原料として使用できる樹種が増え， 各ユーザーの最終製品の多様化も進み, BCTMP, APMP (アルカライン・パーオキサイド・メカニカル パルプ)などの冬プロセスをはじめ, 1 次と 2 次リファ イニング間の中間洗浄などプロセスのバリエーション も増えていることから, 広範进の運転条件で安定運転 のできるリファイナーが要求されている。

アンドリッツ・スプラウト・バウアー (ASB) 社は シングルディスクリファイナー(SDR), ッインリファ イナーおよび DDR をはじめ，紙パルプ製造機器を製 作・販売している。当社は DDRに関し技術提携を結ぶ とともに，他の形式のリファイナーで構成されるメカ ニカルパルピングシステムについても協力関係にある。 本文では当社がユーザーの協力を得て最近実施してい る DDRの高濃度リファイニングのための新技術，さ らに ASB 社の大容量・高濃度リファイニング用ツイ ンリファイナーおよび最近開発された新型 SB シング ルディスクリファイナーを紹介する。

\subsection{TMP および CTMP プロセス}

ASB 社が最近採用している CTMP プロセスの代 表的なフローシートを図 1-1に示す。チップはウオッ シング後，プレスチーミング，インプレグネーション， スチーミング，リファイニングと処理される。本プロ セスは使用される材種, 要求されるパルプ品質に応じ
て各亡程での処理条件，温度および時間が最適になる よう設定する。また最近では 2 段インプレグネーショ ン, 1 次， 2 次リファイニング間での洗浄なども採用 されている。TMPの場合にはインプレグネーション 工程が省略される。リファイナーは処理量, 熱回収の 条件, 目標とするパルプ品質などにより，その形式， 設備動力, 運転条件が決吼る。1次，2次リファイ ナーとも加压型で，リファイニングでの発生蒸気を回 収する場合の ASB 社の TMP システム例を図 1-2に 示す。

\subsection{DDR における新技術}

\subsubsection{DDR での高濃度リファイニング}

DDR は ASB 社の大型りファイナーのうち, 我が国 でTMP，CTMP プラント用として最も多く使用され ている機種であるが，回転ディスクを介して原料を供 給するという構造上の制約から, 高濃度リファイニン グの実現が困難であった。DDR 用新型原料供給装置と して開発されたトップワインダーフィーダーおよびコ アキシャルフィーダーはアメリカ，カナダをはじめ海 外では 10 年以上前に既設 DDR への取付がはじまり， 今では DDRの標準装置となっている。我が国では一 定の運転時間の経過後にディスクを逆回転させ，リ ファイニングプレートの両エッジを使用するという運 転方法が取られているため, リボンスクリュー型コア キシャルフィーダーを主軸に取付けることは，ディス クの回転方向を限定することになり，リファイニング プレートの寿命が短くなることと，パルプ品質の低下

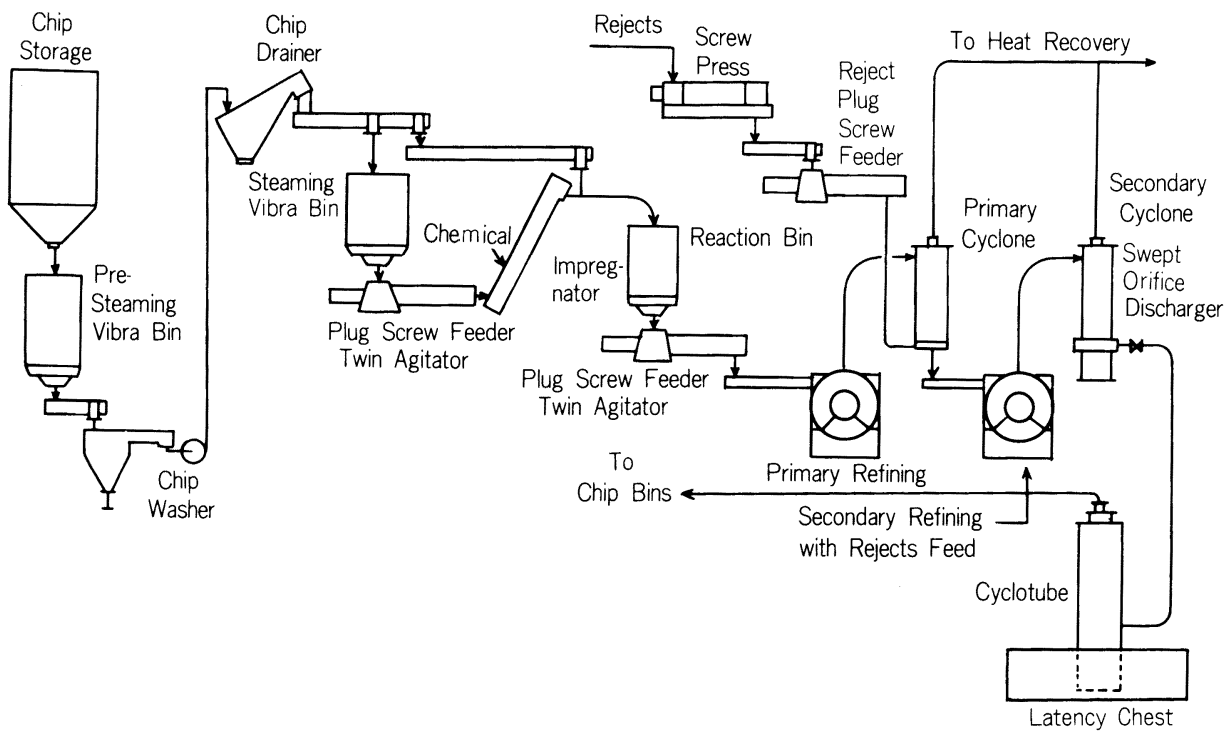

図 1-1 CTMPプロセス 


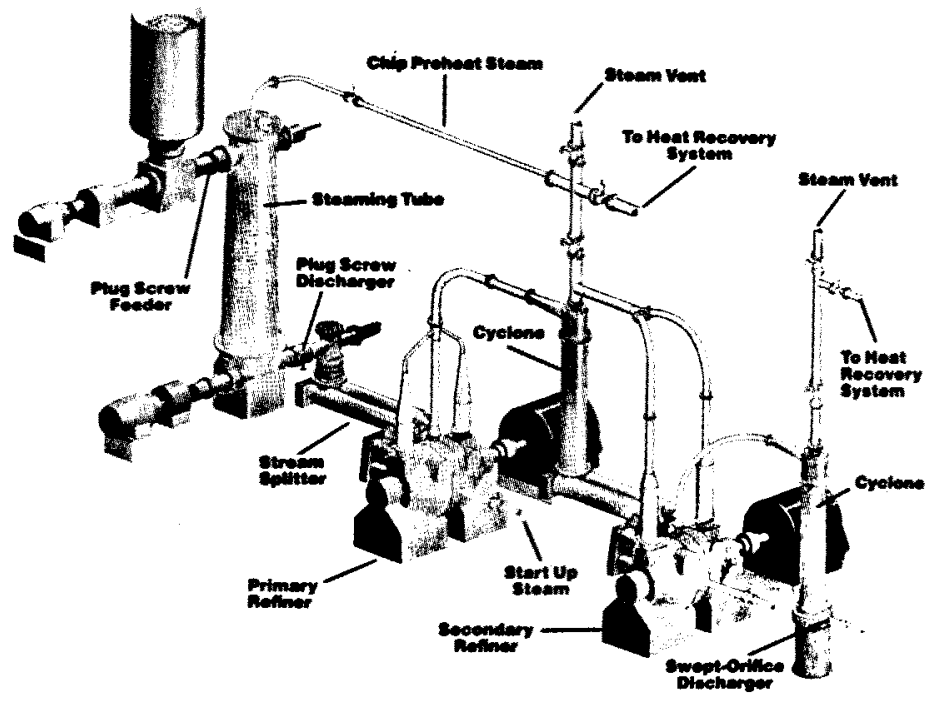

図 1-2 TMPプロセス

などが䒈念され普及が遅れていた。

\section{3 .2 新型原料供給装置}

海外での運転結果を参考に, 当社では各ユーザーに 本コアキシャルフィーダーの取付を推奖し、ユーザー の協力を得て 1988 年に第 1 号機の取付を行った。 取付後の運転結果では，パルプ品質上の問題もなく， 負荷動力が安定し, 約 30\%の高浱度りファイニングが 達成できた。また取付前よりも広いプレート間陌での 運転のため，両エッジを使用する場合よりもプレート 寿命が伸びたとの報告もあり好結果を得ている。

1）コアキシャルフィーダー

コアキシャルフィーダーおよU゙トップワインダー フィーダーを図 1-3 に示す。コアキシャルフィーダー は原料供給側のリファイナ一主軸に取付くリボン型ス クリューで, 主軸と同し回転数で回転する。本フィー ダーは原料をりファイニングゾーンへ均一に供給する とともに、リファイニングでの発生蒸気を空間部から 排出させる。㞍り蒸気がスムーズに排出されるため, ブローバックが解消され，負荷が安定し従来型のよう に多量のプラクワイパー水を供給する必要がなく，そ の分リファイニング濃度が高くなる。コアキシャル フィーターーは加圧型, 大気压型, 1次, 2 次に関係な く大型 DDRに取付けが可能である。

2) トッブワインダーフィーダー

トップワインダーフィーダーは, 従来のッインスク リューフィーダーの代りに使用寸る。このリボン型ス クリューフィーダーは発生蒸気を原料の流れと逆方向 にスムーズに排出し，コアキシャルフィーダーへ原料

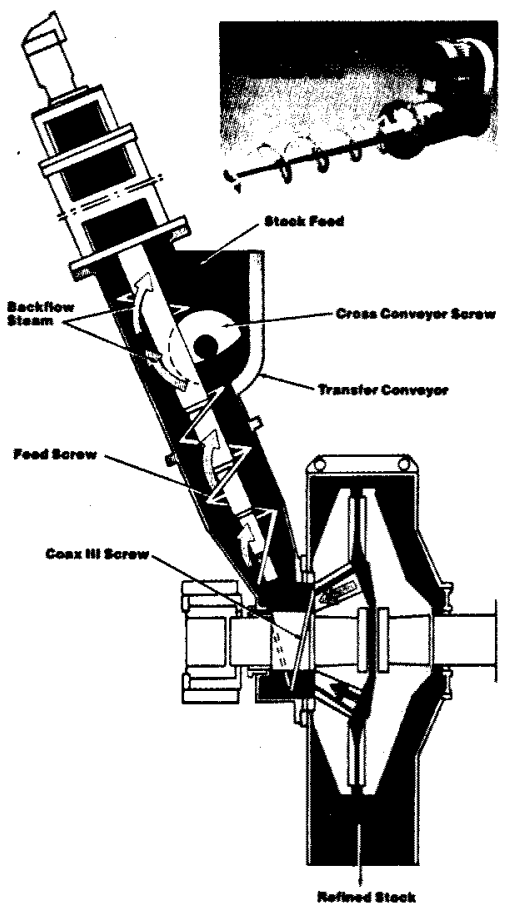

図 1-3 トップワインダーフィーダー

を安定して供給する。コアキシャルフィーダー、トッ プワインダーフィーダーとも加圧，大気压 DDRに取 付けられるが, ファイバーに比べ比重の大きいチップ を报う1次りファイナーではコアキシャルフィーダー のみを設け，トップワインダーフイーダーは設ける必 


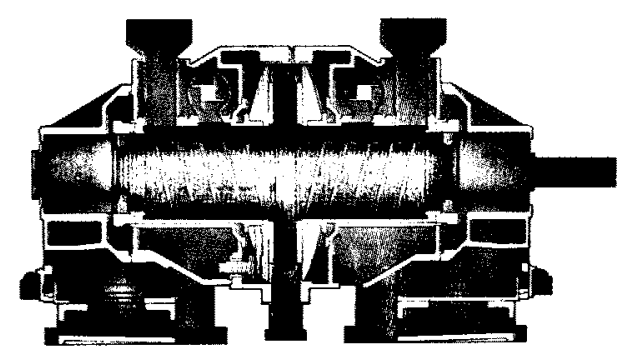

图 1-4 ッインリファイナーの構造

要がない。

\section{4 ツインリファイナー}

\subsection{1 ツインリファイナーの構造}

ッインリファイナーでは图 1-4に示すように，回転 ディスクの両側にリファイニングプレートが取付く。

本リファイナーは 1 台でSDR 2 台分のリファイ二 ンゾーンを持つユニークな構造のリファイナーである。 回転デイスク両側がリファイニングに利用でき, 同し 径のディスクを持つ他の形式のリファイナー, SDRお よび DDR に比べ約 2 倍のリファイニング面積となる。 従ってディスク径を基蕉にすれば，他の形式のリファ イナーの 2 倍の処理能力となり，また他の形式のリ ファイナーと同じモーターを装備すれば, 同じ負荷が 2 倍のリファイニング面積でかけられ，リファイニン ク・インテンシティー（単位プレート面積当りの負荷 動力）が少なくなり，高品質のパルブが得られる。

\section{4 .2 稼動状況}

ツインリファイナーは我が国では TW-50 型 3 基が 輸入され，CTMP およびRGP 用として使用されてい るにすぎなが, 本機は今までの主力機種で, 海外で は 45 inから 60 inのディスク径のッインリファナー 約 150 台が稼動している。最大のものは, $22,000 \mathrm{hp} の$ モーターで駆動きれ，1 系列で約 $400 \mathrm{t} / \mathrm{d}$ の CTMPを 生産している。

\section{4 .3 ッインリファイナーの特長}

1) スラスト力のバランス

回転部分はディスクが中央にあり主軸雨端がラジア ル軸受で支持される。プレート間淂は静止側プレート ホルダーを油圧シリンダーで移動させ調節する。本構 造のディスクには両側から等しい力が加わるためスラ スト力が相殺される。ディスクには曲げ応力も発生し ない。従って加圧下，大気压下のどのようなリファイ ニンク压力条件下でも，スラスト力によるディスクお よび機械の変形が発生せず,プレートの平行度が確䒠
に維持され均一な品質のパルプが得られる。また大型 スラスト軸受を設ける必要がなく、リファイナ一本体 が非常にコンバクトであり，潤滑システムも小型であ る。

\section{2) 原料供給装置}

原料はロードセンシング・コンベヤーを通り、リボ ンフィーダーへ供給される。ロードセンシンダ・コン ベやーは左右のリボンフィーダー上部に取付计られ原 料切れや詰まりを検知する。従ってリファイニンク ゾーンでの原料切れが発生する前に信号によりプレー トホルダーが後退し, 軽負荷によるブレートの接触が 防止できる。主軸に取付くリボンフィーダーはディス クと同し高速回転で原料を供給すると同時にリファイ ニングにより発生する蒸気を排出する。高速回転りボ ンスクリューの遠心力に上り, 原料はスクリュー外周 側を通り中央部には十分な空間ができる。高濃度り ファイニングで発生する多量の蒸気も原料供給を妨げ ることなく排出される。また大型, 高速リボンフィー ダーは効率よく蒸気と繊維を分離し, 蒸気排出口が 2 ケ所あることも回収蒸気中に同伴するパルプを少なく する。

3）その他，本リファイナーは次の特長がある。

・左右对称形の機械であるため, 熱膨張による変形が 少ない

・中央部が大きく開く構造のため, ブレート交換が容 易で所要時間も短い

\section{5 新型シングルディスクリファイナー (SDR)}

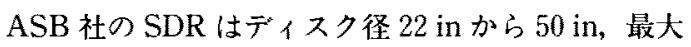
装備動力 $6,700 \mathrm{hp}$ であった。最近, 今までの各形式の リファイナー製作経験に基づき，コンパクトであらゆ

る用途に使用できる新型 SDR が開発された。 本リファイナーはSB型と名付けられ，゙ィスク径

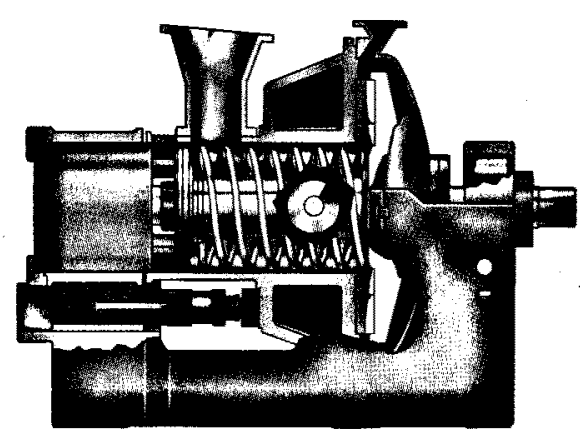

図 1-5 SB 型シングルディスクリファイナー 
60 in $の$ SB-150 型と 66 in S SB-170 型の 2 機種があ る。本リファイナーの構造を図1-5に示す。

本機は既にフランスの Feldmuhle Beghin 社, Papeteries de Golbey 社などから合計 6 基 ASB 社が 受注し，うち 3 基は稼働している。

\subsection{1 リファイニング条件}

最大のパルプ強度を得るためには 30 - 55\%の高濃 度りファイニング，一方，優れた光学的特性を確保寸 るには30\%以下の低濃度リファイニングが推奖され ている。高濃度りファイニングでは多量の発生蒸気を スムーズに排出しながら，原料を安定して供給するこ とが重要である。一方, 低濃度りファイニング, 特に ディスク径の大きいSDRでは，遠心力により原料が リファイニンダソ゚ーンを速く移動し，リファイニング プレートの間に存在する原料の量が少なくなるため, プレート間隔を㹨くする連転が必要である。SB型り ファイナーはこのような設計コンセプトのもとに開発 され、低濃度から高濃度までの㕕い濃度域でプレート 間鄚を正確に維持し，安定運転を可能とする頑丈なり ファイナーである。

\section{5 .2 特 長}

1) スラスト力対策

プレートギャップの調節は図1-6に示すように国定 側プレートホルダーに取付く油压シリンダーにより可 転ディスクを固定側ブレートホルダー側に引き笴せて 行う。このユニークな構造のため, ベースにはスラス ト力が発生しない。しかもコンパクトであるため機械

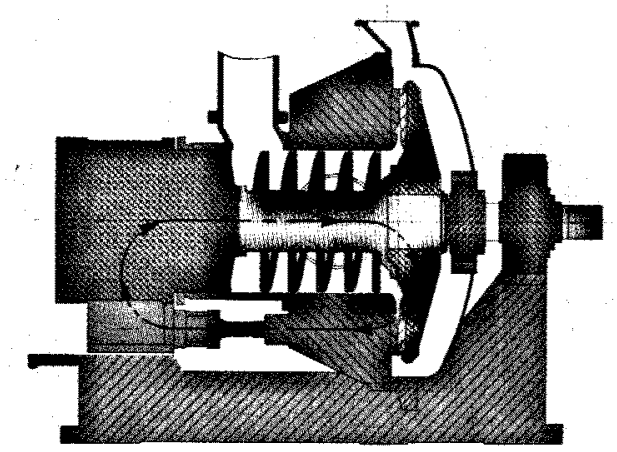

図 1-6 SB 型シングルディスクリファイナーの 構造図

の変形が少なく、プレートの平行度か確寒に維持され る。スラスト軸受は大型スベリ軸受を使用し、リファ イニングで発生する全スラスト力が受けられる。促っ てディスク前後 (リファイニング部とケーシング側) にスラスト力を隇少させるための差压取る必要がな く，リファイナーの運転条件が自由に設定できる。こ の差压を調節することにより、リファイニング時間が 変わり，パルプ品質を変えることもできる。

2) 原料フィーダー

原料供給用りボンフィーダーは主軸に直接取付けら れ、ディスクと同じ速度で回転する。本フィーダーは ッインリファイナーのリボンフィーダーと同様, スク リュー羽根が大きく高速で回転する。原料㹥逆流する

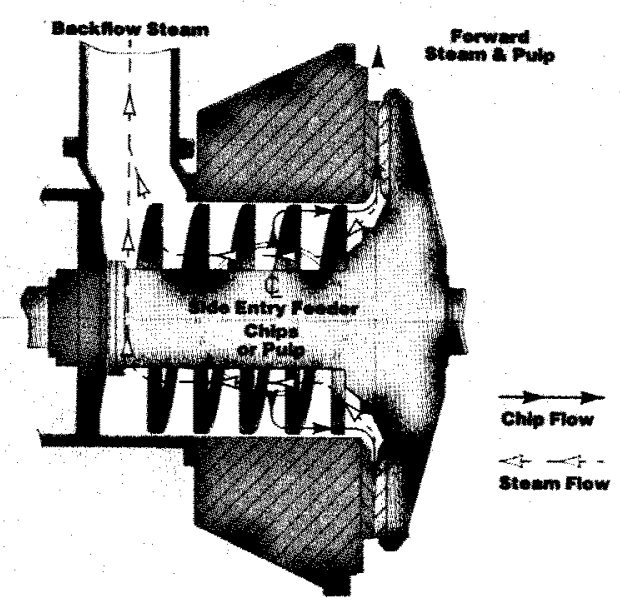

図 1-7 SB 型シンダルディスクリファイナーの原料 フィーダー 
発生蒸気に妨げられることがなく, 安定してリファイ ニング部へ供給される。リボンフィーダーへ原料を供 給するサイドエントリーフィーダーは図 1-7 に示すよ うにディスクに近い位置に取付けられている。発生蒸 気の排出口はサイドエントリーフィーダーよりも後方 にある。この配置関係から回収蒸気中への纎維の同伴 が最小になる。

3）ローターの支持

回転ディスクは径の大きい主軸の中央に組込まれ， 回転部は両端 2 ケ所のラジアル軸受で支持される。 オーバーハング部がなく, 非常にシンプルな構造であ り, 軸心の狂いがなく良好な動バランス特性をもって いる。

4) 軸受

ベアリングハウジングが大型でカートリッジ式の取 換方式を採用している。万一, 軸受を取換える場合に も回転部を抜出す必要がない。

5）プレート間隙調節装置

プレート間隙は油圧サーボ制御システムで調節する。

本システムはリファイニング状況の変化に迅速に応 答して正確な制御を行い, 均一なパルプ品質が得られ る。プレート間隙制御には差压コントロールと位置コ
ントロールの 2 種の選択ができる。またプレート間隙 センサーも取付けられる。ケーシングはリファイナー 中央部にあり, 原料供給側のケーシングが大きく後退 するため, プレート取換時に広いスペースが確保され プレート交換が容易に行える。

以上述べたように，本リファイナーはコンパクトで 高性能, あらゆる使用条件に対応できる新型リファイ ナーである。外形および機長を図 1-8に示す。

\section{$1.6 \mathrm{SDR}$ と DDR の比較}

現在では各リファイナーメーカーが SDR と DDR の両形式のリファイナーを販売するため, この比較は 大きな問題ではなくなったが, 形式選択上での当社の 考えを述べる。

\subsection{1 原料供給方法}

DDR は回転しているディスクに設けられた開孔か ら原料を供給し, SDR は静止ディスク側から原料を供 給する。ディスク間で発生した蒸気は DDR, SDR とも 原料の供給と逆方向に排出させるが, DDRにおいては 蒸気も回転するディスク開孔から逃す必要がある。 従ってDDRにおける原料供給はSDRのそれと比較 して複雑なものとなり, DDRの構造上の問題点であ
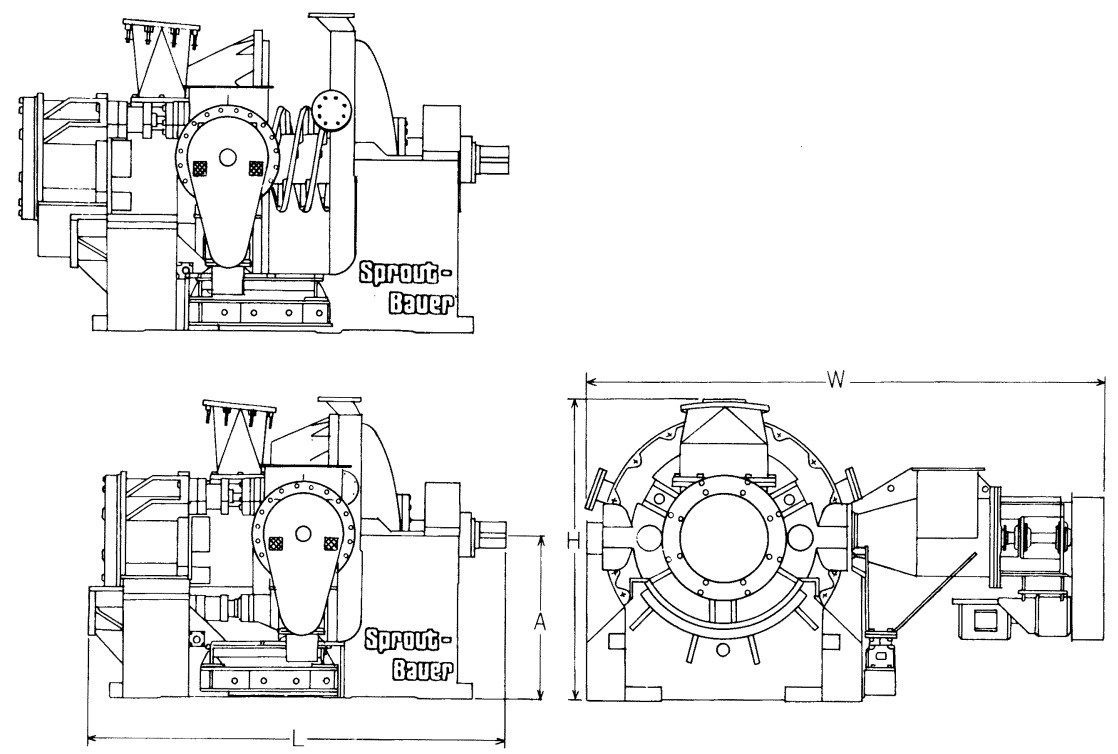

\begin{tabular}{cc|c|c|c|c}
\hline & & \multicolumn{4}{|c}{ 寸法(mm) } \\
\cline { 3 - 6 } & $L$ & W & $H$ & $A$ \\
\hline SB & 150 & 3,380 & 4,200 & 2,440 & 1,320 \\
\hline SB & 170 & 3,665 & 4,370 & 2,660 & 1,400 \\
\hline
\end{tabular}

図 1-8 SB 型シングルディスクリファイナーの外形网と寸法 
る。

\subsection{2 インレット部シールの問題}

DDR においてはフィードエンドの回転ディスクと 八ウジングの間をシールする必要があるが, 運転時の 熱膨張のため, このシールを適正に調整することが難 しく，リファイニングされたパルプ中の結束繊維含有 率が多くなる。従って後工程のスクリーニングが重要 となる。一方, SDRにおいてはこれに相当するシール 部分がないため, 結束繊維含有率の少ないパルプが得 られる。

\section{6 .3 ディスク間における原料の挙動}

\section{1）両ディスクの相対速度}

一般に DDR は $60 \mathrm{~Hz}, 50 \mathrm{~Hz}$ の電源周波数でそれぞ れ 1,200, 1,500 rpm, SDR は 1,800, 1,500 rpm で運 転されている。しかし相対速度の観点からは, DDR は 2つの回転するディスクを持っているため，それぞれ 2,400, 3,000 rpm で運転されていると言える。従って 同一条件下 (周波数, プレート間隙, プレートパター ン等が同一) の運転ではDDR の方がディスクの相対 速度が大きく，リファイナーに与えられたエネルギー はよりマイルド，かつ頻繁にチップに伝わり，マイル ドなリファイニングが期待できる。

2）プレート間の原料に働く遠心力

原料は遠心力によってプレート間を移動すると言わ れている。DDR では両側のディスクが互いに逆方向に 回転しているので，各々のディスクで発生する遠心力 はある程度まで相殺され，原料はゆっくりとプレート 間を移動する。従って同一条件下の運転ではDDRの 方がSDR よりプレート間隙を広く運転できるため, より大きな繊維間摩擦作用が得られ，この差が生産さ
れるパルプ品質の違いになると一般に理解されている。

\section{6 .4 プレート間隙とリファイニング濃度}

高品質の機械パルプは繊維とプレートの接触によっ てではなく，繊維同志の吒解作用によって得られると 言われている。プレート間隙を増すと繊維間の作用は 増え, 繊維とプレートの接触は少なくなる。その結果, より大きなフィブリル化と，より少ない纎維の切断と なる。これはより柔軟な繊維を作り，結合力を增加さ せることになる。パルプ強度はリファイナーに加えら れるエネルギーに直接関係するが，極端にプレート間 陌を小さくするとパルプ強度が損なわれる程の繊維の 切断を引起こす。濃度を高くして嵩高な状態にするこ とにより，プレート間隙を大きくすることができる。 広く認められているように，リファイニング濃度を上 げるほど，より高品質のメカニカルパルプが得られる。 高濃度で繊維はより大きな摩擦係数を持ち, エネル

表 1-1 日立造船 アンドリッツ・スプラウト・ バウアーダブルディスクリファイナー

\begin{tabular}{|c|c|c|c|c|}
\hline \multicolumn{2}{|l|}{ 型 } & \multirow{2}{*}{$\begin{array}{l}\text { プレート径 } \\
\text { (in } / \mathrm{mm})\end{array}$} & \multirow{2}{*}{$\begin{array}{l}\text { 最大設備 } \\
\text { 動力 (hp) }\end{array}$} & \multirow{2}{*}{$\begin{array}{c}\text { 機器重量 } \\
\text { (ton) }\end{array}$} \\
\hline 加圧型 & 大気圧型 & & & \\
\hline $485-23$ & $489-23$ & $65 / 1,651$ & 20,000 & 77 \\
\hline $485-22$ & $489-22$ & $60 / 1,524$ & 15,000 & 77 \\
\hline $485-8$ & $489-8$ & $56 / 1,422$ & 12,000 & 68 \\
\hline $485-6$ & $489-6$ & $52 / 1,321$ & 10,000 & 59 \\
\hline $420-\mathrm{P}$ & $420-\mathrm{A}$ & $40 / 1,016$ & 4,000 & 20 \\
\hline \multirow[t]{3}{*}{418} & & $36 / 914$ & 3,000 & 12 \\
\hline & 413 & $44 / 1,118$ & 3,000 & 22 \\
\hline & 412 & $40 / 1,016$ & 2,000 & 12 \\
\hline
\end{tabular}

表 1-2 アンドリッツ・スプラウト・バウアーシングルおよびッインリファイナー

\begin{tabular}{|c|c|c|c|c|c|}
\hline & \multicolumn{2}{|l|}{ 型 } & \multirow{2}{*}{$\begin{array}{l}\text { プレート径 } \\
\text { (in/mm) }\end{array}$} & \multirow{2}{*}{$\begin{array}{c}\text { 最大設備動力 } \\
\text { (hp) }\end{array}$} & \multirow{2}{*}{$\begin{array}{l}\text { 機器重量 } \\
\text { (ton) }\end{array}$} \\
\hline & 加 圧 型 & 大気圧型 & & & \\
\hline 新型シングル & \multirow{2}{*}{\multicolumn{2}{|c|}{$\begin{array}{l}\text { SB-150 } \\
\text { SB-170 }\end{array}$}} & $60 / 1,524$ & 16,000 & 30 \\
\hline ディスクリファイナー & & & $66 / 1,676$ & 20,000 & 35 \\
\hline \multirow{4}{*}{ ツインリファイナー } & \multirow{4}{*}{\multicolumn{2}{|c|}{$\begin{array}{cc}\text { TWIN } 60 \\
\text { TWIN } 54 \\
\text { TWIN } 50 \\
\text { TWIN } 45\end{array}$}} & $60 / 1,524$ & 22,000 & 45 \\
\hline & & & $54 / 1,372$ & 16,000 & 28 \\
\hline & & & $50 / 1,270$ & 14,000 & 27 \\
\hline & & & $45 / 1,143$ & 10,000 & 18 \\
\hline \multirow{4}{*}{$\begin{array}{c}\text { シングルディスク } \\
\text { リファイナー }\end{array}$} & $50-1 \mathrm{CP}$ & $50-1 \mathrm{C} / \mathrm{B}$ & $50 / 1,270$ & 6,700 & \\
\hline & $45-1 \mathrm{CP}$ & $45-1 \mathrm{C} / \mathrm{B}$ & $45 / 1,143$ & 4,500 & \\
\hline & $42-1 \mathrm{CP}$ & $42-1 \mathrm{C} / \mathrm{B}$ & $42 / 1,067$ & 3,000 & \\
\hline & $36-1 \mathrm{CP}$ & $36-1 \mathrm{C} / \mathrm{B}$ & $36 / 914$ & 1,000 & \\
\hline
\end{tabular}


ギーをより多く吸収できるからである。一方，リファ イニング濃度が $20 \%$ 割ると, 繊維の切断がおこり強 度が損なわれる。これらのことはSDR, DDRの両リ ファイナーにおいて言える。SDRの方が DDRよりも 相当に高濃度で運転され，これがSDRの持つ大きな 利点の一つだとされている。DDR では回転ディスクか ら蒸気を逃がさなくてはならないという問題から, 高 濃度リファイニングにはいくつかの困難があった。し かし現在では, 本稿に記述しているとおり, DDRに トップワインダー, コアキシャルフィーダーを装備す ることにより, 約 $30 \%$ の高濃度リファイニングが可能 となっている。

\section{6 .5 適切なリファイナーの選定}

とにかく両形式のリファイナーとも, 必要とする品 質のパルプを造ることが可能と言える。SDR は構造が 非常にシンプルで大型化しやすい。一方, DDR は高散 乱係数を有し，ファインを多く含んだ嵩高でないパル プを製造するのにより適したものになる。また DDR ではシーリングの問題から結束繊維含有率が高くなる が, これはスクリーン設備で除去しなければならない。 各形式, サイズのリファイナー一覧表を表 1-1，2 に示 す。

\section{まとめ}

以上 3 機種のリファイナーを紹介させて頂いた。

DDR, SDR, ツインリファイナーはそれぞれ特長が あり, プロセス，樹種及び製造されるパルプ品質によ り，適切な機種を選定することが重要であると考える。 当社および ASB 社では各形式のリファイナーの開発, 改善の努力を続け, ユーザーのニーズに応じたメカニ カルパルピングを供給していく所存である。

今後とも皆様方のご指導とご鞭撻をお願いしたい。

\section{一第 2 部一}

\section{日立造船富岡機械／スルザー・エッシャー ウイスの原料調成用リファイナー}

\section{日立造船富岡機械株式会社 原調開発部}

\section{1 はじめに}

日立造船富岡機械株式会社はドイツのスルザー・ エッシャーウイス社との間に全面的な技術提携を行い, 抄紙機，原料調成および古紙処理機器を製造している。 この中にはダブルディスクリファイナーとコニカル リファイナーが含まれており, 表 2-1に示す概略仕様 となっている。スルザー・エッシャーウイス社はヨー ロッパを中心に数多くの実績を有しており，世界的に
評価を得ている。同社は日々研究開発を進め，非常に ユニークな高性能機器を発表し, さらに標準化を進め ている。リファイナーについても同様で，実験結果か ら生れたジーヴァート，ゼル多一両氏による論文を同 社のリファイナーに対する考え方の一端を示すものと してご参考に供する次第である。

\section{2 パルプのリファイニングにおける}

\section{エネルギーの経済的利用}

$$
\begin{aligned}
& \text { スルザー・エッシャーウイス社 } \\
& \text { W.H.ジーヴァート, H.ゼルダー }
\end{aligned}
$$

\section{2 .1 まえがき}

これまでは纎維懸濁液のリファイニングを検討する 場合，常に抄紙特性に主眼が置かれてきた。これは当 然最も重要ではあるが, エネルギーの観点だけからリ ファイニングを分析してみるのも我々にとって注目の 価値があるように思える。それはリファイニングが, 実は繊維懸濁液の物理的特性を变化させるためにエネ ルギーを加えることを意味するからである。主に検討 するのは次の事柄である。

・全生産コストに対するエネルギー必要度の重要性

・エネルギーを最も効果的に使う方法, 例えば機械的, 流体力学的, 超音波等

・エネルギーがいかに有効にパルプ懸濁液の性質に変 化をもたらすか

・リファイニングエネルギーを低減するにはどのよう な可能性があるか

\section{2 .2 生産コストに対するリファイニングエネル ギーの重要性}

調查によると文 1980 年にはドイッの製紙工場での 電力, 蒸気を合わせた全エネルギーコストは技術水準 や製品にもよるが生産コストの約 12 17\%を占めて いた。これはさほど大きな割合ではない。さらにこれ を分析してみると，ティッシュではリファイニングが 全エネルギーコストの約 7\%を占めるのに対して, 液 状でリファイニングする紙では $35 \%$ にもなる。従って リファイニングは全生産コストの約 1～6\%というこ とになる。この值は小さいようであるが，工場の利益 率が低い場合，節約源が潜在することは紙生産の経済 性に直接大きな影響をもたらし得るため, リファイニ ングは重要な要素なのである。

\section{2 .3 リファイニクングへのエネルギー付加の可} 能性

色々な物理的原理をリファイニングに応用した科学 論文が多数出されている。そのいくつかを例として取 り上げて見よう。Jayme と Rosenfeld ${ }^{2}$ は $800 \mathrm{kHz}$ 付 
表 2-1 日立造船 スルザー・エッシャーウイスダブルディスク およびコニカルリファイナー

\begin{tabular}{r|c|c|c|c}
\hline & 型 式 & $\begin{array}{c}\text { 最大設備動力 } \\
(\mathrm{kW})\end{array}$ & $\begin{array}{c}\text { 回 転 数 } \\
(\mathrm{rpm})\end{array}$ & \multicolumn{1}{|c}{$\begin{array}{c}\text { 処 理 流量 } \\
(\mathrm{l} / \mathrm{min})\end{array}$} \\
\hline & DSR 1 & 250 & $1,000 / 900$ & $300-1,800$ \\
ダブルデフィスク & DSR 2 & 450 & $750 / 720$ & $500-3,500$ \\
リファイナー & DSR 3 & 750 & $600 / 600$ & $800-5,000$ \\
& DSR 4 & 1,400 & $450 / 450$ & $1,600-10,000$ \\
\hline & $\mathrm{R} 1$ & 15 & $1,500 / 1,800$ & $50-180$ \\
コニカルリファイナー & $\mathrm{R} 2$ & 110 & $1,000 / 900$ & $200-1,100$ \\
& $\mathrm{R} 3$ & 200 & $750 / 720$ & $500-2,000$ \\
\hline
\end{tabular}

近の超音波で繊維の弛緩が達成できることを立証した。 しかしエネルギー消費が通常の方式の数百倍も高いの でこの方法は実用的でない。キャビテーションに関す るあるソ連の文献 ${ }^{31}$ によれば, 繊維の抄紙上の挙動に ある程度の効果があるが, エネルギー消費の原単位に は触れていない。Pav, Slabina, Soucek は流体力学的 な振動発生器によって原料ジェットの動エネルギーを 転換し, $10 \mathrm{kHz}$ の振動周波数で繊維を同様に弛緩でき たと報告している4)。エネルギー原単位はほぼデフ レーカーのものと同等であるが, 純振動エネルギーに よる効果はごく一部分でしかないと報告者たちも言っ ており，それが正しいであろう。機械的流体力学的な 要素も大きな影響があったはずであり，そうでなけれ ば Jayme と Rosenfeld の得た結果との大差が説明で きない。リファイニング効果はポンプ輸送できる濃度 の繊維原料懸濁液と, 動く機械要素の間の剪断応力に よっても同様に達成出来る。コニカルリファイナーを 用いてフィリング間の隙間 $0.6 \mathrm{~mm}$ の時，またデフ レーカーで陌間 $1.5 \mathrm{~mm}$ の時の実験結果がある ${ }^{5,6) 。 こ ~}$ の隙間はフィリングが機械的作用を起こしてモーター の負荷が明確に増加する時の值より2ないし10 倍大 きい。強度水準では非常に高い一方，エネルギー消費 量は今日工場で普通に見られる値の約 10 倍であった。 $20 \%$ 以の高濃度において繊維間の摩擦力と剪断力は 非常に高い6)。ここでは流体力学的損失は全モーター 動力のうち小さい割合しか占めないので, エネルギー 必要量は前記の例に比べて非常に低い。必要エネル ギー量はここでも通常のリファイニングの 2 倍である。 バーのエッジを使って繊維を機械的に処理することは 一般的に用いられる技術として確立された。この原理 を用いて抄紙特性を最小のエネルギー消費で得ること ができ,この特性は多くの場合要求に合致したものと なる。従って経済的に妥協した点が存在する。

\subsection{4 エネルギー消費量の分析}

リファイニングに使用したエネルギーは三つに分類 できる。

・有効リファイニングエネルギー

・機械の可動部分による無負荷エネルギー

・システム関係のエネルギー

有効リファイニングエネルギーはフィリングと運転 方法によって決まる。無負荷動力は設計, 寸法, 速度, フィリングの状態によって決まる。速度, フィリング は機械の設計とレイアウトによる。システムに関連す るエネルギーは生産パターンとこれに関係したシステ ムの対応による。この最後の要素はプラントの多様性 が増すとますます重要になる。

\section{2 .5 有効リファイニングエネルギー}

まず有効りファイニングエネルギーから始める。リ ファイナープラントを調整する作業を計算するべース になる項目は次のものがある（図 2-1）。

・フィリングの形式。抄紙品質特性の変化パターンを 決定する主要要素である。

・エッジ負荷原単位 $\mathrm{Bs}(\mathrm{Ws} / \mathrm{km})$ 。ある特定のフィリ ング形式に対する抄紙品質特性の変化パターンを決 定する。

・有効リファイニングエネルギー原単位（kWh/100 $\mathrm{kg})$ 。リファイニングの必要程度を性格づける。ある

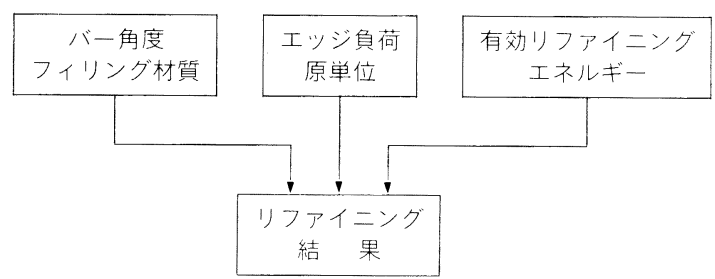

図 2-1 リファイニングの結果に影響する主要要素 
特定の抄紙特性の発達について一定のポイントを設 定する。

これらの概念は図 2-2のように定義づける。前に説 明したように，バーエッジがリファイニング作用の大 部分を行い，一方，バー表面の作用など他の影響は証 明はできるものの重要性が低い。厳密に言えば有効り ファイニングエネルギー $\mathrm{Ne}$ は次式で定義される。

$$
\mathrm{Ne}=\mathrm{Nek}+\mathrm{Nef}(\mathrm{kW})
$$

ここに Nek はエッジの, また Nef は表面の有効り ファイニングエネルギーを表す。どの程度までエッジ と表面で実際にリファイニングエネルギーが伝達され るかという疑問が生じる。エッジが全くない滑らかな フィリングはリファイニング表面の全有効リファイニ ングエネルギーを原料に伝達し (図 2-3), この場合次 の式が成り立つ。

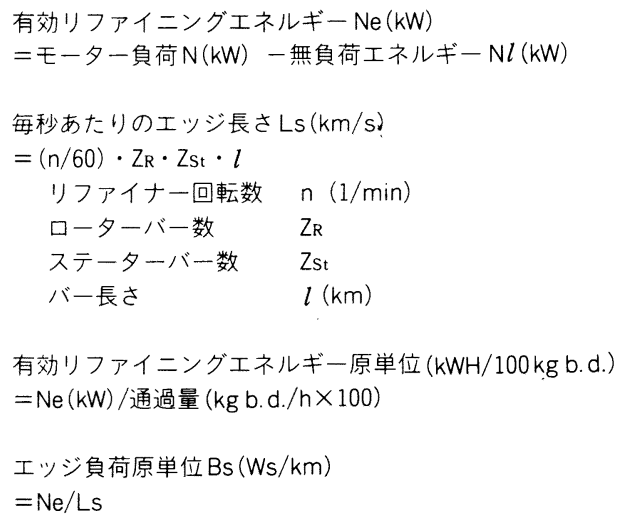

図 2-2 式の定義

$$
\begin{aligned}
& \mathrm{Ne}=\mathrm{Nef} \\
& \text { バーエッジの数が増加すると, 表面によって伝達さ }
\end{aligned}
$$
れるリファイニングエネルギーの割合は減少し, 理論 的には厚さが小さい有限数のエッジだけが存在すると いう極端な場合にいたる。ここでは

$$
\mathrm{Ne}=\mathrm{Nek}
$$

有効リファイニングエネルギーの変動によってカー ブは平行移動する。しかし実用上はバーエッジがリ ファイニング工程で最も重要な影響を持つため, 有効 リファイニングエネルギーを全部バーエッジに関係づ けることで十分であることが立証された。

色々なバー幅やバー本数を持つフィリングによる実 際の知見からこのことが確認されている。同程度の変 動について, 同じモータ一負荷の場合, リファイニン グ表面の大きいフィリングは（摩耗にさらされる質量 が大きいにも係わらず）毎秒当りのバー長さの大きい フィリングよりも寿命が短いことが分かった。このこ とは, 前述のようにエッジ負荷原単位がより重要な要 素であることを示している。そこでリファイナーの寸 法と台数はフィリングとその負荷条件だけによること になる。図 2-4の左上は低角度のカッティング用フィ リングと, 広角度のフィブリル化用フィリングで同じ バー材質のものでフリーネスで表したリファイニング 結果が異なった負荷に対しどう変化するかの 1 例を示 す。ある与えられたフリーネス值についてカッティン グ作用のあるフィリングは常にそのバー角度と負荷原 単位のためにエネルギー所要量が小さいことが分かっ た。従ってカッティング作用はエネルギー消費が低い。 しかしエッジ負荷原単位は無制限に増加させることは

Effective refining energy $\mathrm{NeK}$ (bar edges)

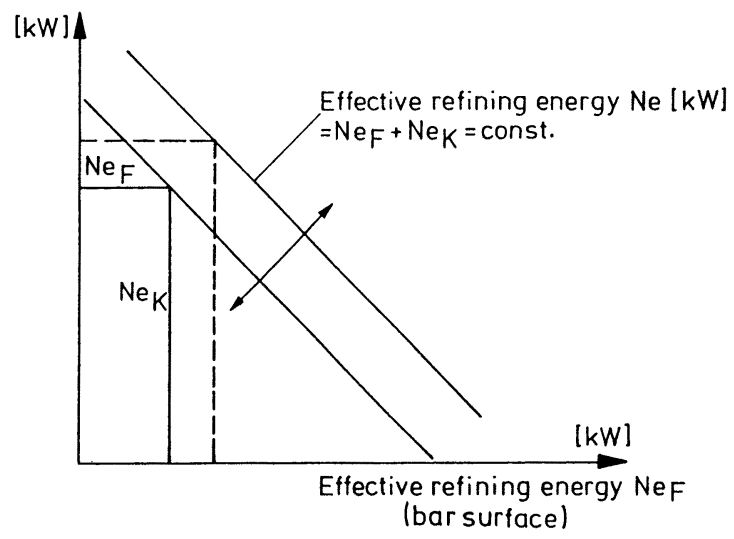

図 2-3 有効リファイニングエネルギー $\mathrm{Ne}$ のバー表面と エッジへの分布想定 


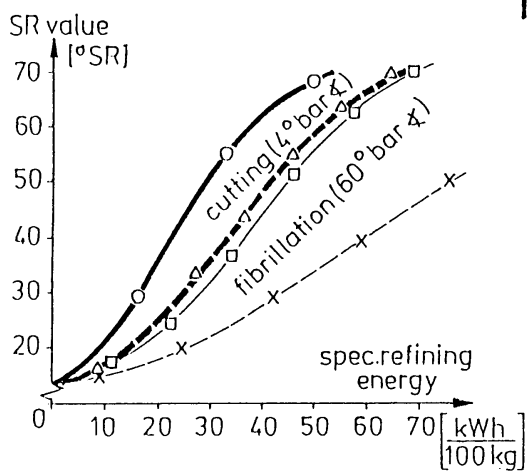

Slock: bleached pine sulphate $=B_{s}=3000 \frac{\mathrm{Ws}}{\mathrm{km}}$
$=-二 B_{s}=1500 \frac{\mathrm{Ws}}{\mathrm{km}}$

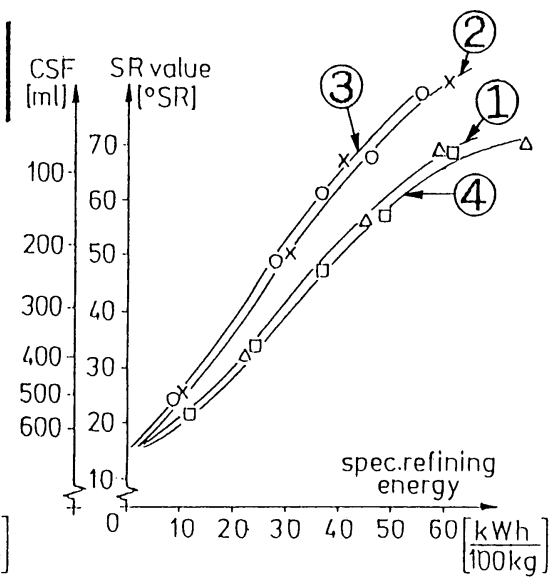

Slock: unbleached spruce sulphite

(1) - $B_{s}=600 \frac{\mathrm{Ws}}{\mathrm{km}}$

(2) $-B_{S}=1200 \frac{\mathrm{Ws}}{\mathrm{km}}$

(3) $-B_{s}=2200 \frac{\mathrm{Ws}}{\mathrm{km}}$

(4) $-B_{s}=3600 \frac{\mathrm{Ws}}{\mathrm{km}}$

図 2-4 色々な運転条件下でのリファイニング挙動

できない。グラフの右半分はエゾマツの未晒クラフト パルプにおける関係を示す。パルプはまず負荷条件 $\mathrm{Bs}=600$ から $2,200 \mathrm{Ws} / \mathrm{km}$ の間でリファイニングし, 極端な場合は $3,600 \mathrm{Ws} / \mathrm{km}$ まで上げた。最初リファ イニングエネルギー原単位の節減量は増加したが, 負 荷が増大するにつれて次第に減り，ついには損失にさ えなったことが明かに分かる。

従って各パルプについてリファイニングエネルギー の効果的な利用には最適点があり，それぞれの場合の 原料性状による。繊維長が短く, 弱いパルプでは負荷 $\mathrm{Bs}=1,000 \sim 2,000 \mathrm{Ws} / \mathrm{km}$ の範囲でリファイニング 出来るが, 長纎維クラフトパルプでは $\mathrm{Bs}=4,000 \mathrm{Ws} /$ $\mathrm{km}$ まで負荷がかかる。これがリファイニングの用法 と経済性に関係してくるが，これについては後で触れ る。リファイニングした原料の抄紙特性も当然異なる。 図 2-5に引張, 引裂，長繊維成分によりこれを示す。 フィブリル化用フィリングおよび負荷の低いフィリン グはあるフリーネスについて強度が常に高い。しかし これはエネルギー消費が高い状態で達成された。これ に加えてフィリングの材質がリファイニングエネル ギーに対して重要な要素になる。

これを示すために，松の未晒クラフトバルプを色々 な材質のフィリングでリファイニングした。同じ材質
でも冶金学的な前処理の相違による変動があった。図 2-6はその結果の様態である。ある特定のフリーネス を得るためのエネルギー所要量は約 40 ～60\%変動す る。前と同様にこれは抄紙特性に大きな相違をもたら す。エネルギー所要量が最も高いリファイニングでは 強度が最も良い。この理由はテスト中連続して変化を 観察したエッジのところに見られる。テストは絶対的 に比較可能な条件下で行われた。図 2-7はリファイ ナーバーとその表面のテスト後の拡大写真である。先 端は非常に異なった形状になっているのが明確に分か る。ブロンズのフィリングは鋭いエッジであるのに, オーステナイト系鋳鉄は丸くなっている。あらゆるリ ファイニングテストの結果はこの条件で分類するとう まく行く。他の材料特性, 例之ば機械的, 物理的性質 や材料分析に関係づける試みは観察結果を満足に説明 出来なかった。結局, バーエッジの形状が事実上エネ ルギーを支配しており，エネルギー所要量と抄紙特性 に関してリファイニング結果の決定的要素であること を仮定せざるを得ない。さらにこのことから,バーエッ ジが常に鋭く保たれるように，経済的なフィリングで 急速に摩耗させることが必要であると結論づけること ができる。長い寿命を持つフィリングはエッジの進行 方向先端が丸くなり一方，後端は長持ちする。 
$=B_{s}=3000 \frac{W s}{\mathrm{~km}}$

=-二的 $=1500 \frac{\mathrm{Ws}}{\mathrm{km}}$

Stock: bleached pine sulphate

$=$ cutting

- fibrillating

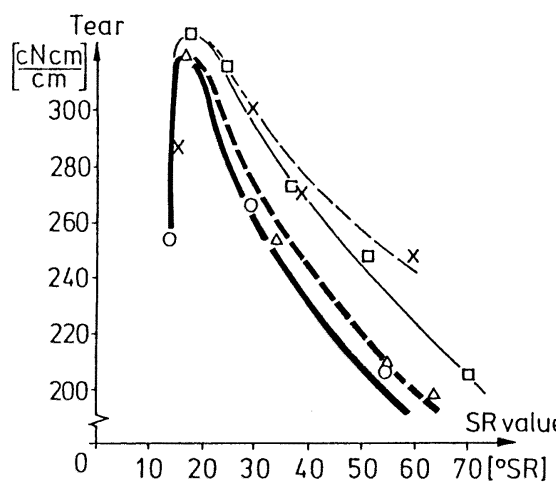

図 2-5 松 BKP のリファイニング挙動

$S R$ value
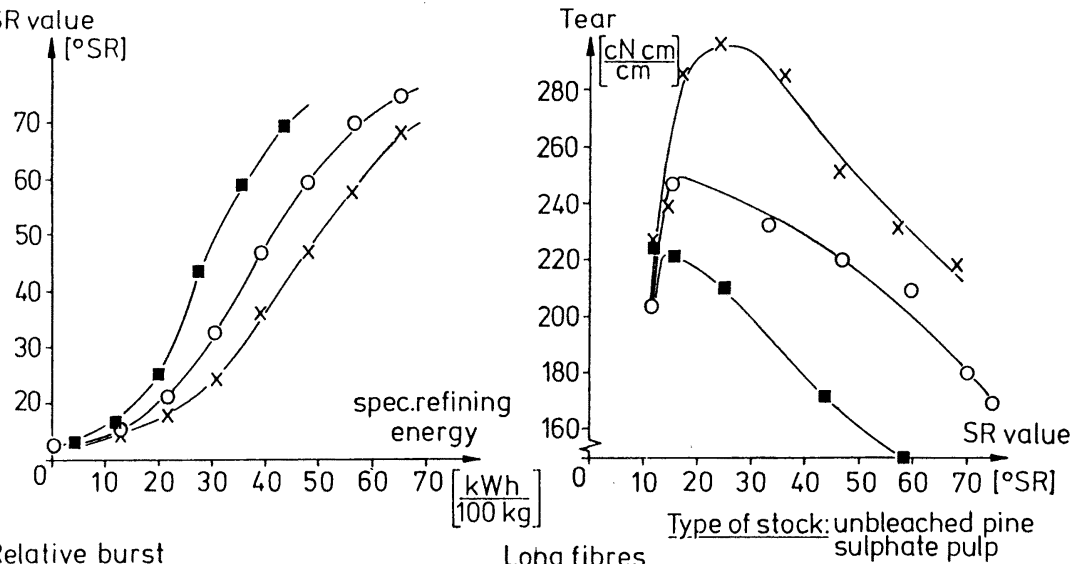

Relative burs

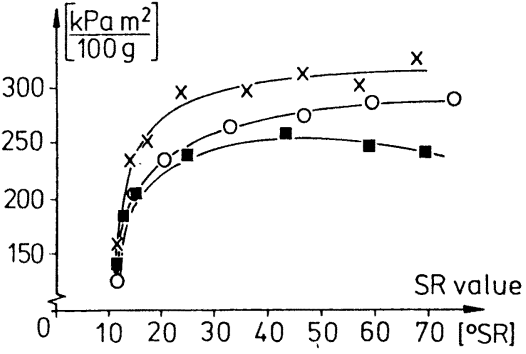

Long fibres
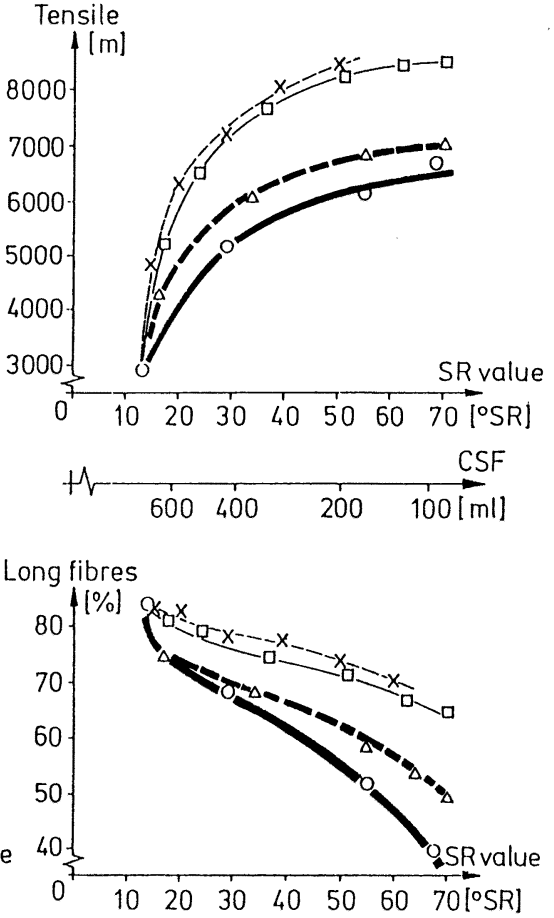

\section{SF}

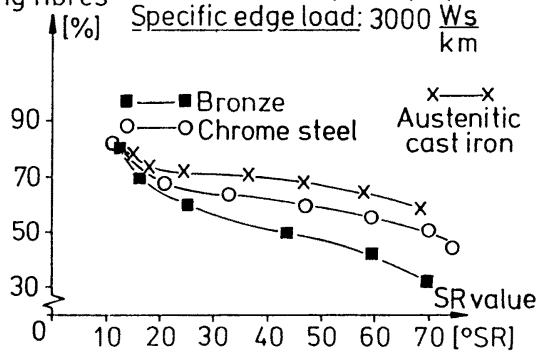

図 2-6 フィリング材質選定がエネルギー消費とリファイニング効果に与える影響 


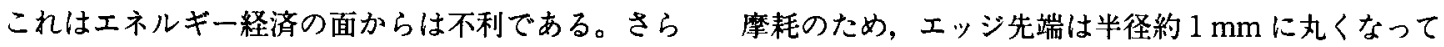
に摩耗したフィブリル化用フィリングを用いてリファ いたが後端は鋭い。フィリングを正逆両方向に回転さ イニングテストを行った (図 2-8)。連続運転中の材料せリファイニングの様子を観察した。あるフリーネス

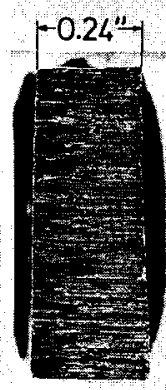

Bronze

View..."

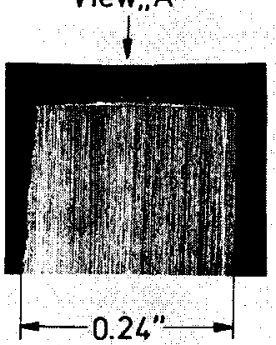

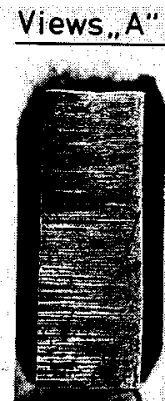

Chrome steel

View., A"

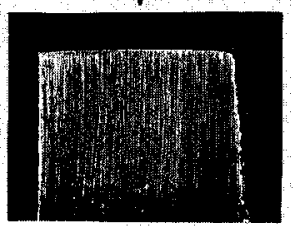

Direction of rotation

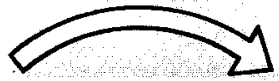

図 2-7 リファイナー・バーの拡大写真

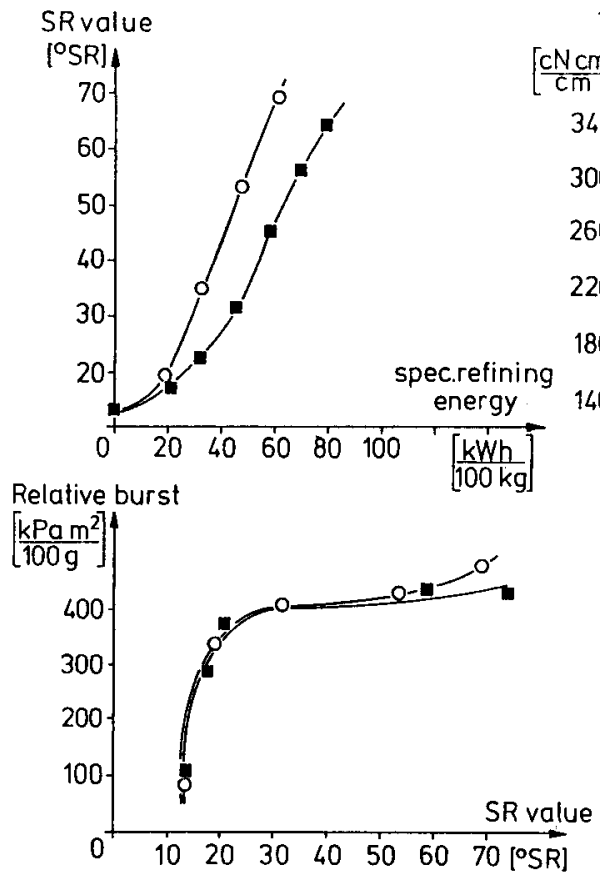

Tear
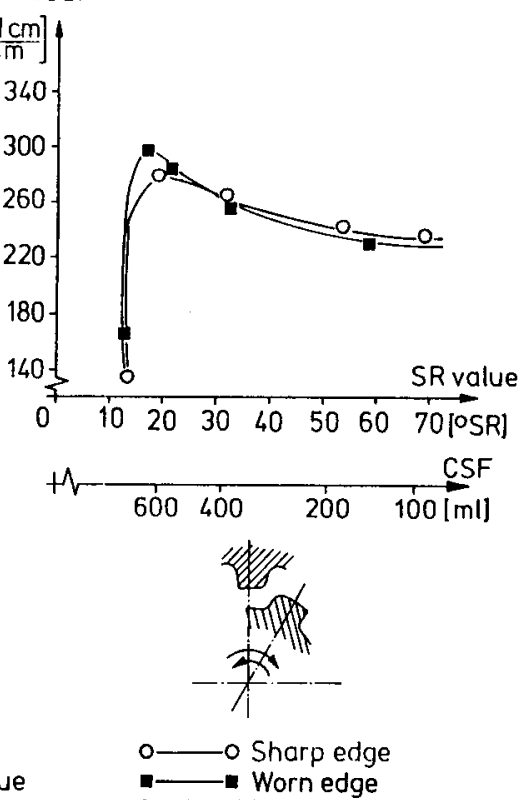

Stock: unbleached pine sulphate $B_{\mathrm{s}}=3000 \frac{\mathrm{Ws}_{\mathrm{s}}}{\mathrm{km}}$

図 2-8 運転方法がエネルギー消費とリファイニング効果に与える影響 
に達するまでに, 丸いエッジの方が鋭いものよりはる かに多くのエネルギーを消費することが再び示され， その差は 30〜50\%になった。抄紙特性については変動 は前述の場合よりもかなり小さかった。これはいずれ の場合でも強いフィブリル化作用をもつフィリングの 効果がエッジの変形によりさらに進行することがない ためである。しかし，前と同じようにエッジ先端が丸 いと, より稳やかなりファイニングが行われる傾向に あることが分かる。集約すると有効りファイニングエ ネルギーは広い範囲で変えることが出来るが, 常に抄 紙特性の同時变動に結び付く。だが生産上の要求の方 がエネルギー節隇より常に優先されるから, リファイ ニングの経済性はここではあまり影響を与えることが 出来ない。

\section{2 .6 無負荷エネルギー}

しかしながら，あるリファイナーについて無負荷エ ネルギーに関しては状況がまた異なる。この無負荷エ ネルギーの明確な定義を得るために，リファイニング 効果をもたらさないエネルギー消費要素すべてを無負 荷エネルギーと決め, 機械を空の状態でまわすエネル ギーと, 満水状態でまわすエネルギーすなわち無負荷 エネルギーをリファイニングエネルギーから差し引く (図 2-9)。しかし原料で満たされた状態でリファイ ナーを運転するときの無負荷エネルギーは, 我々の定 義によればリファイニングエネルギーの一部として算 定されている。その理由はこのエネルギーによってあ る程度のリファイニング効果が繊維に与えられ, また この值はリファイニング中にいつも変動し, ほとんど

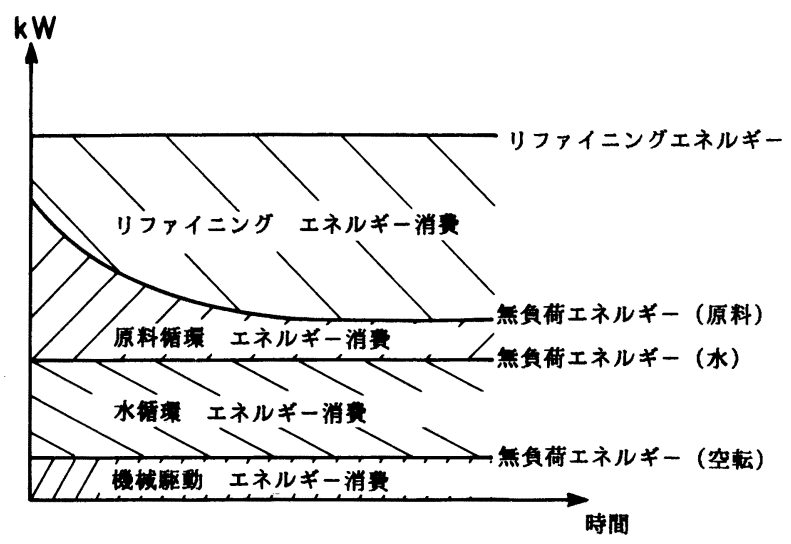

図 2-9 リファイニング・エネルギーの分布

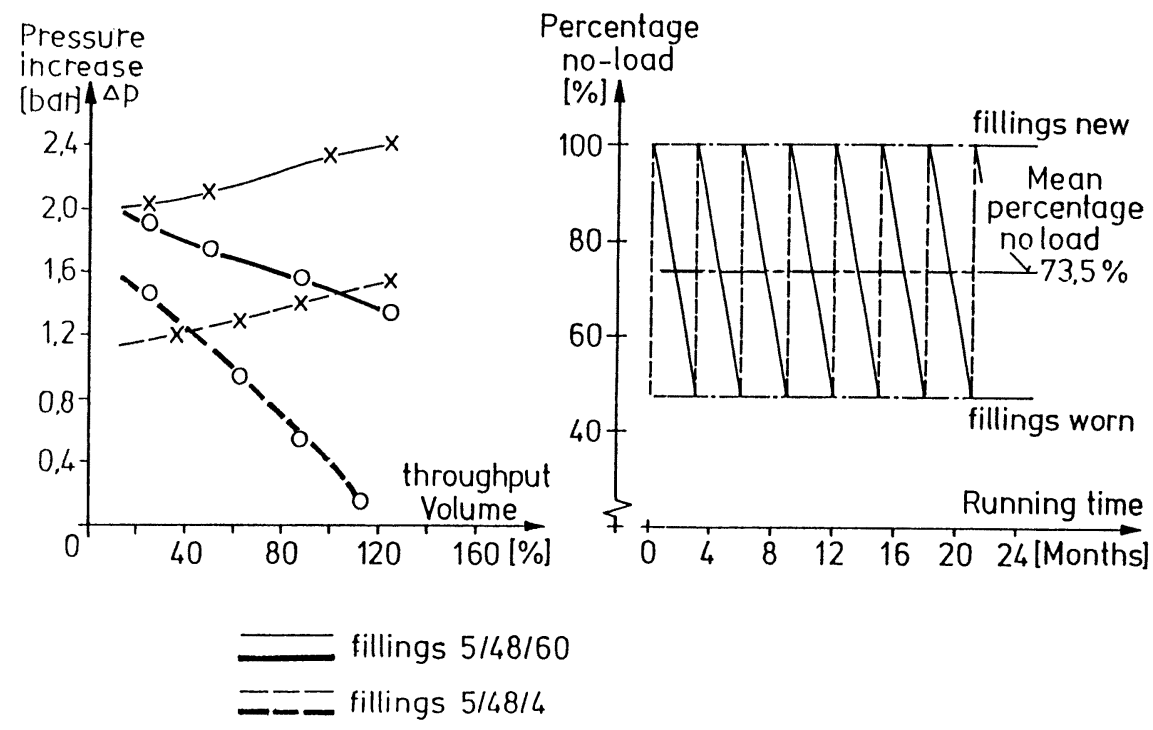

図 2-10 DDR の無負荷エネルギー 
正確に記録できないからである。無負荷エネルギーは 色々なパラメーターによって影響される(図 2-10)。そ の一つはフィリングの圧力関係である。

ある流体通過量に対して，圧力が高まると無負荷エ ネルギーは図 2-10 の左半分に角度の大小について示 すように大きく増加する。通過量が増すと圧力上昇は 減るが, 処理流量が大きいためモーターの負荷はなお 増大する。このグラフはまたリファイナーのポンプ効 率が悪いことをも示していて興味深い。ある流量に対 して一定の圧力上昇のためには，ポンプはダブルディ スクリファイナーの 1/20 しか動力を要しない。

従って, 常にポンプ作用はポンプに任せ, リファイ ナーは最小の圧力上昇で運転することを推奨したい。

但し前述のように，無負荷エネルギーは一定値を取 らず, フィリングの使用期間に従って変動する（図 2-10右)。溝の深さと無負荷エネルギーの間には直線 関係が存在する。従ってダブルディスクリファイナー では，エネルギー効率を最も高くするにはバーは $2 \mathrm{~mm}$ まで摩耗させるべきである。前段のポンプが圧 力の変化を補えるならば通過量の低下は起こらない。 しかしこれはグラフに示すように平均無負荷エネル ギーに大きく影響する。バーが摩耗した結果, 平均無 負荷エネルギーは新しいフィリングの時の $73.5 \%$ に なる。

溝が深いと寿命が長くなるため, フィリングのコス 卜は最小になるが，一方では同時に無負荷エネルギー にはマイナスの影響が生じる。従って設計には経済上 の最適点があるに違いない。最適化計算 (図 2-11) に よれば，通常の条件下で運転するダブルディスクリ ファイナーの場合, 最も経済的な溝深さは 6 から 7 $\mathrm{mm}$ のところにある。これはもちろん動力コストと材
料コストにもよる。動力コストが低い場合には溝を深 くする方向に変り, 材料コストが低いと反対の方向に なる。

しかしカーブの合計が相対的に平らであるという性 質から，標準フィリングでどの客先にも対応すること が出来る。無負荷エネルギーは回転数の約 3 乗に比例 するが，毎秒あたりのエッジ長 Ls は前に示したよう に正比例する。速度を低下させると $\mathrm{Ne} / \mathrm{N} 1$ の関係が より好ましい方に変って行く。これを $\mathrm{Bs}=1,000$ およ び 3,500 Ws/km の時の例で示す。

一方で有効リファイニングエネルギー原単位は増加 する。二つの影響要素は総合すると全リファイニング エネルギー原単位には小さな差しかもたらさないので, 全エネルギーの消費原単位を大きく変えることなく速 度を $1: 2$ の範囲で変化させることが可能である。

図 2-12 はまたどの程度まで最大許容リファイナー 負荷がその結果同時に変化するかを示している。

トルク関係からくる許容リファイナー軸負荷の変化 は直線である。無負荷エネルギーは回転数の 3 乗で変 化するから, 機械的な観点からは高いリファイナー負 荷原単位が低い回転数範囲で得られる,すなわち一定 のフィリング負荷原単位に対して最大許容軸負荷から 離れる安全性が高い。低速域は従って特定の高エッジ 負荷原単位用に設計されたフィリングに適しているの に対して高速域は低エッジ負荷原単位に向いており, 不満足なリファイナ一使用法を少しでも改善するのに 役立つ。前述の例では $450 \mathrm{rpm}$ と $\mathrm{Bs}=1,000 \mathrm{Ws} / \mathrm{km}$ の時, リファイナーはモータ一負荷がわずか約 $9 \mathrm{~kW}$ であるのに，3,500 Ws/ km では $220 \mathrm{~kW}$ になる。900 rpmではいずれの場合も可能なモータ一負荷は 2 倍 になった。しかし $\mathrm{N} / \mathrm{N} 1$ の比は悪い方に動き, $\mathrm{Bs}=$

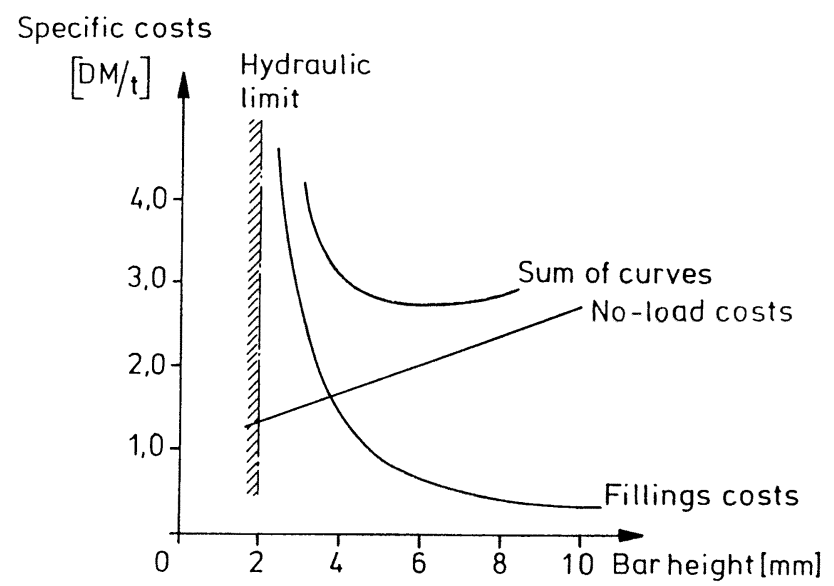

図 2-11 DDR フィリングの運転コスト最適化 


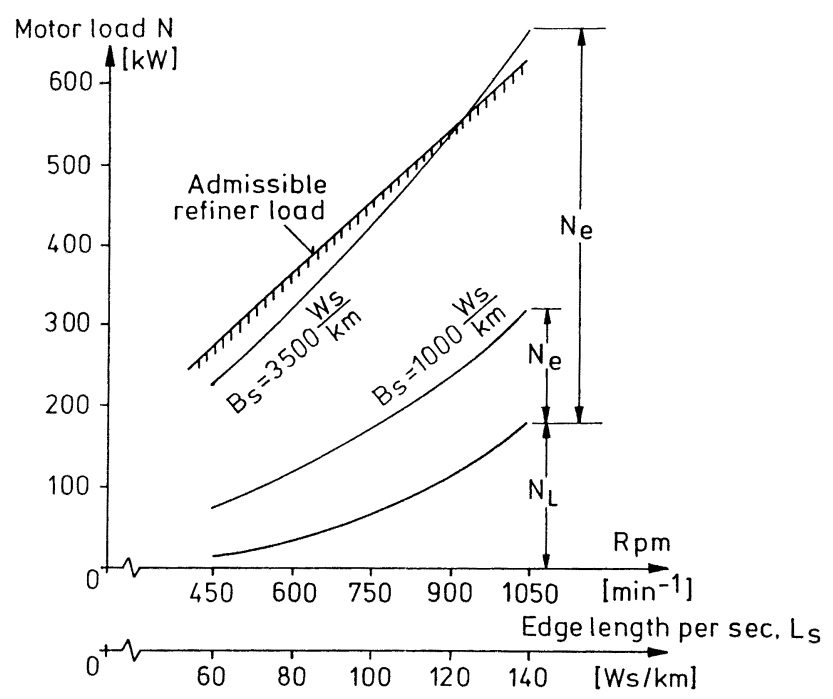

図 2-12 速度変化が負荷と効率に与える影響

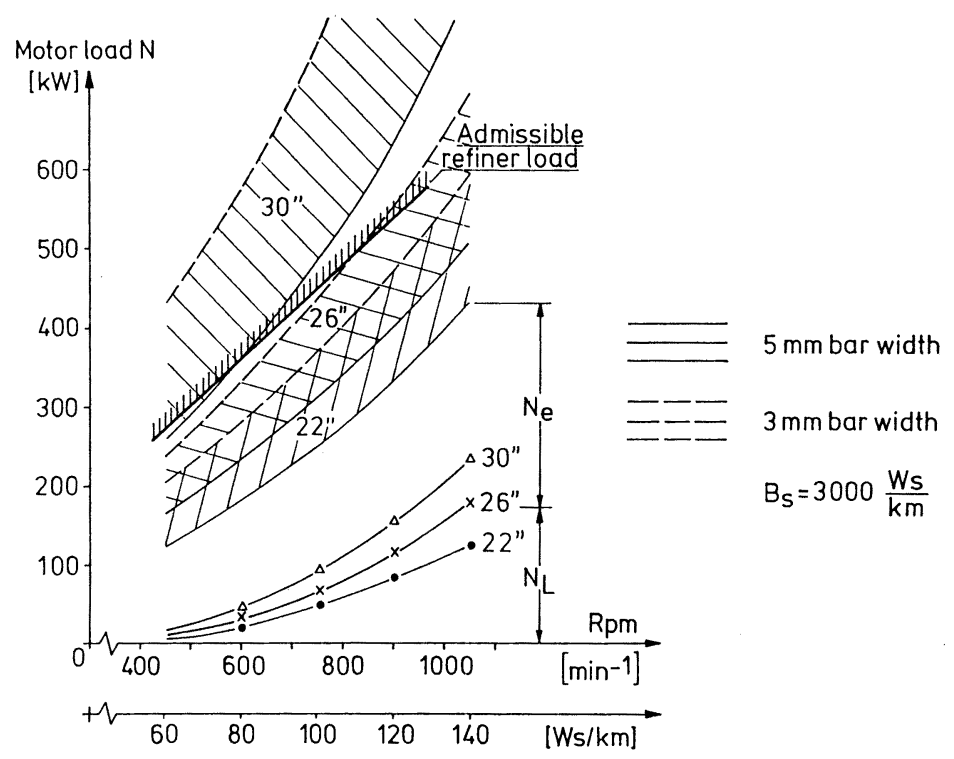

図 2-13 直径と速度の変化が負荷と効率に与える影響

$3,500 \mathrm{Ws} / \mathrm{km}$ の場合 $7 \%$ から $25 \%$ に，また $\mathrm{Bs}=1,000$ Ws $/ \mathrm{km}$ では $17 \%$ から $50 \%$ になった。運転上の理由で 全リファイナーエネルギーが例えば $500 \mathrm{~kW}$ 必要な場 合 (必要生産量, ある抄紙特性に対する特定のエッジ 負荷原単位によるリファイニングエネルギー原単位お よび与えられたフィリングの組合せによって算出され

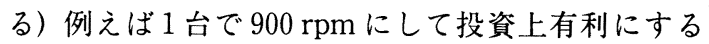

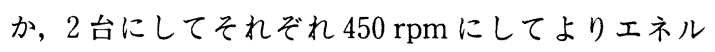
ギー節減を計るかという疑問を生じる。グラフはまた 1 組のフィリングでは低負荷原単位の場合, リファイ
ナーの潜在能力が完全には引き出せない危険があり, また一方では高負荷原単位の場合, 能力をオーバーし てしまう危険があることも示している。

この理由のために, どのリファイナーサイズにも 色々な直径のフィリング数種を常備している。あるリ ファイナーの, ある速度について直径を大きくして行 くと，その表面の変化の 2 乗に比例して無負荷エネル ギーが増すが回転数の 3 乗に比例して増加する毎秒あ たりのエッジ長 Ls の変化よりは小さい（図 2-13）。 エッジ負荷原単位 Bs が低い場合, リファイナーの 
負荷可能率は高くなり, 同時に $\mathrm{N} / \mathrm{N} 1$ 比もより好まし いものになる。グラフはまたどの負荷範囲が今日使わ れている各種のフィリング形式, 速度に重なるかをも 定義している。これはある特定のリファイナー形式と, 特定のエッジ負荷 Bsに対して当てはまるものである。 リファイナー使用の最適值に到るには, フィリングと 速度を慎重に選ぶことによって必要なリファイナー負 荷への最善の策を見出すことにある。例えば $300 \mathrm{~kW}$ の負荷で図に示したフィリング 3 種はいずれも使用出 来るが, $450 \mathrm{~kW}$ では 30 in のフィリングは完全に負荷 をかけることが出来ないため使用出来ない。実用上, リファイナーはそれぞれ数種類の用途に対して設計さ れているから, あらゆる第 2 義的な要素を盛り込んだ 結果限界にぶつかることがよくある。限界とはリファ イナー運転の最適方法について妥協を受け入れなけれ ばならないことである。従うべき基本原則はリファイ ナー負荷が最大許容值に出来るだけ近い状態で運転出 来るよjにフィリングを選定することである。これに よってエネルギーがもっとも効率よく利用出来る。

\section{2 .7 システム関連のエネルギー}

これまでに検討したリファイナー自身の内部ですべ て処理でき, ある特定の運転条件にすべて関連する工 ネルギー節減方法とは別に, この運転状態がどれほど 実際に起こるのかということも考虑するべきである。 既存のリファイナー能力は工場で実際に必要なものと 対応しないことが多い。その結果, かなり長期の生産 期間にわたって, リファイニング能力が過剩となり, 最大許容負荷で運転しないから使い方がまずくて使用 効率が悪くなる。何台かを停止するか, 速度を変えて
リファイナー能力を実際の運転状況に合わせて調整す ることが必要になる。数台を数段階にわけて停止する には小型機を数多くもたなくてはならないが，速度を 変えることは連続，無段階変化で速度に比例する毎秒 あたりのエッジ長 Ls の調整が変えられる。このこと はレイアウトを最適にするのに適当な策である。

生産計画に大きな幅がある場合には, 効率を最適に 保ちながらリファイナー能力を調整出来る。速度調整 はリファイニング効果の均一性についても有利である。

既に示したように，ある特定の抄紙特性を得ること は特定のエッジ負荷 Bs とリファイニングエネルギー 原単位に対応する。今日, 通常のリファイナ一負荷制 御（図 2-14）は実際のリファイナー負荷を測定し設定 值と比較する。設定值との偏差をフィリング間の隙間 を再調整して補正する。これはエッジ負荷原単位を変 え, 従って抄紙特性を変える。さらに加えて, 例えば チェスト液面の変動による通過量の変化はリファイ ナ一負荷が一定であってもリファイニングエネルギー 原単位の変化の原因となり抄紙特性の変化になる。

実用上は例えばリファイナーの大多数を一定負荷, すなわち一定のリファイニング進行で運転し，1ない し2台のリファイナーで負荷と通過量の総量によって 大体一定のリファイニングエネルギー原単位を保つよ うに運転することによってこの影響に限界を与えるこ とが試みられている。これは負荷制御に通過量制御を 重ねることに基づいている。しかし今日では制御コン ピューターが濃度とモーター負荷から絶乾通過量制御 を可能にしており，これから設定值とするリファイニ ングエネルギー原単位を計算できるようになっている。

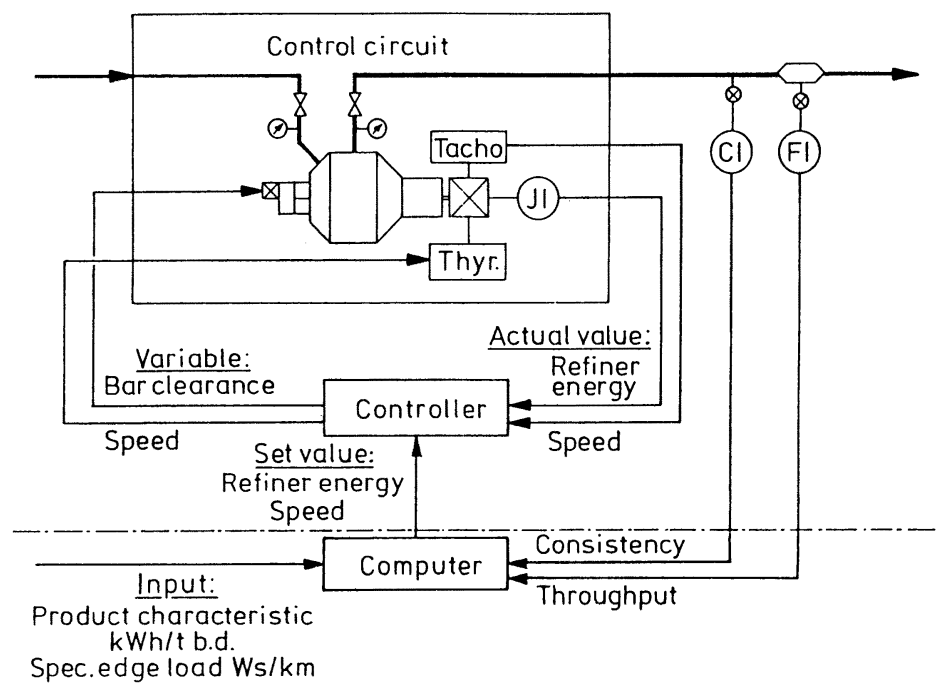

図 2-14 通過量に基くリファイナー制御 
なお残っているのは制御調整がなされた場合の毎秒 あたりのエッジ負荷の差による抄紙特性の変化である。

コンピューターでの計算に一旦速度を取り入れれば, リファイニングエネルギー原単位と毎秒あたりのエッ ジ負荷の両方を必要全範囲にわたって適合するように 調整出来る。あるリファイナーのモーター負荷と速度 の調整係数は当初コンピューターに与える無負荷エネ ルギーの指数関数変化と通過量に比例して変化するリ ファイニングエネルギー原単位から計算される。調整 值はほほいつもモータ一負荷から計算される。リファ イニング工程の指標としての有効リファイニングエネ ルギーは間接的に計算され, プログラムに定数として 与えなくてはならない。今起っている実際のリファイ ニング条件を計算するためにモー夕ー効率を用いるこ とは今日まだ広くは行われていない。表 2-2 は色々な 制御方式とその影響のまとめである。これらのシステ ムの経済性を表 2-3に示す。ここにプラント稼働率 $80 \%$ と $60 \%$ の場合の無負荷コスト原単位をリファイ ナーと駆動装置の投資額と比較してみた。リファイ ナー全数に可変速度制御を取付けても, 償却期間は相 对的に短くて 1.6 および 2.6 年である。

1 台だけに可変速駆動を設けても, 設備コストの増 加はある合理的な限度内に納まり, 償却は 2.6 年が
1.3 年と早くなる。リファイナーの速度を用いてリ ファイナー能力を実際に必要な運転能力に調整するこ との可能性とは別に, リファイニングを調整してエネ ルギーの有効使用を達成する他のシステム要素が考え られる。例えばシングルパスと多数回パスの比較, ま たは品種別, 混合リファイニングについては各種の文 献で論じられているのでここでは取り上げない。一方， 分級した繊維懸濁液のリファイニングはまだ正しく明 確になっていないため特に興味深い。分級した繊維の 性質については多くの発表がなされている。ここでは $\left(\mathrm{Arlov}^{7}\right.$ のものをまず取り上げる。分級した各繊維の強 度值はリファイニング工程と繊維長次第で未分級繊維 のものよりも高くも低くもなることを彼は示した。 $\mathrm{Schmut}^{8)}$ はある特定の最終条件に近づいた後の分級 繊維のリファイニングは各級間の移動しか起らず, 各 級それぞれの性質に変化は起らないことを示した。 Szwarcztajn と Przybysz ${ }^{9}$ は微細繊維の影響に関す る色々な異なった説は, 正確には定義づけられていな い粒子寸法の分布に起因することを主に強調した。

リファイニング末処理のパルプ中にある「1 次」微 細繊維はリファイニングには測定可能な影響を及ほささ ないことをも彼らは指摘している。この微細繊維はフ リーネスと原料の結合能力にわずかな変化しか与えな

表 2-2 通過量に基くリファイナー制御

\begin{tabular}{l|c|c}
\hline \multicolumn{1}{c|}{ 制 御 形 式 } & $\begin{array}{c}\text { リファイニング } \\
\text { エネルギー原単位 }\end{array}$ & $\begin{array}{c}\text { エッジ負荷 } \\
\text { 単 位 }\end{array}$ \\
\hline モーター負荷 & 変 動 偏 差 & 直線過比例偏差 \\
\hline $\begin{array}{l}\text { モーター負荷およびリファイニング } \\
\text { エネルギー原単位 一 無負荷の定数 }\end{array}$ & - 定 & 直線 比例 偏差 \\
\hline $\begin{array}{l}\text { リファイニングエネルギー原単位 } \\
\text { およびリファイナー速度 }\end{array}$ & - 定 & - 定 \\
\hline
\end{tabular}

表 2-3 コスト検討

\begin{tabular}{|c|c|c|c|c|c|c|c|c|c|}
\hline \multirow[t]{2}{*}{$\begin{array}{l}\text { 平均 } \\
\text { 運転率 }\end{array}$} & \multirow{2}{*}{$\begin{array}{l}\text { 可変速 } \\
\text { リファ } \\
\text { イナー } \\
\text { の台数 }\end{array}$} & \multicolumn{3}{|c|}{$\begin{array}{c}\text { 設 備 投 資 額 } \\
1,000 \text { ドイツマルク } \\
\text { (リファイナー+駆動) }\end{array}$} & \multicolumn{3}{|c|}{$\begin{array}{c}\text { 無負荷コスト } \\
\text { ドイツマルク/トン }\end{array}$} & \multicolumn{2}{|c|}{ 回 収 期 間 } \\
\hline & & 定 速 & 可変速 & 差 & 定速 & 可変速 & 差 & 運転時間 & 年 \\
\hline \multirow{2}{*}{$80 \%$} & 3 & 630 & 810 & 180 & 7.1 & 3.8 & 3.3 & 20,500 & 2.6 \\
\hline & 1 & 630 & 690 & 60 & 7.1 & 4.9 & 2.2 & 10,200 & 1.3 \\
\hline \multirow{2}{*}{$60 \% *$} & 3 & 630 & 810 & 180 & 9.5 & 2.3 & 7.2 & 12,500 & 1.6 \\
\hline & 1 & 630 & 690 & 60 & 6.3 & 4.9 & 1.4 & 21,400 & 2.7 \\
\hline
\end{tabular}

*リファイナー 2 台運転のとき。

DSR 2 型リファイナー 3 台のリファイニングシステムの例 
い。一方, リファイニング中に生じる「2次」微細繊 維は特にフリーネスに決定的な影響を与える。これを 除去すると引裂は良くなるが引張は悪化する。フリー ネスと引張の利益, 不利益を天科にかけると, 微細繊 維を除去するほうが有利という結論になる。フリーネ スパターンの評価は残念ながらリファイニング期間で しか定義できないが, 原料の繊維分は同等の引張また は引裂を得るのにかなり長い間リファイニングしなく てはならないという結論である。同時にこのことは非 常に高いエネルギー所要量原単位が要ることをも意味 する。従って分級リファイニングの利点は微細纎維の 除去にあるのではなく, 弱目のリファイニングで長繊 維のフリーネスを高目にしておき，これに微細繊維を 加えることにある。この技術を組み込んだプロセスは かなりの投資を要するため, 今日この基準によるプラ ントはまだ少数である。さらに分級に用いる機器の機 能から生じる容積分布に存在する問題のため工程内に 余裕がない。スルザーエッシャーウイスでは特にリ ファイニング用に分級した分量を調整する方法を準備 しているが，その説明は本稿の範囲を外れるので省き， そのシステムは高濃度スクリーニングですでに成功し ている制御原理を基本にしているとだけ述べておく。 システム調整によるエネルギー節減は今日リファイニ ングを減らし薬品を使うことによっても達成出来る。 ここでは纎維の変化を機械的方式によらず，低リファ イニングの繊維の結合力を外部の影響により増加させ ている。

\section{引用文献}

1) Results of statistical investigations.
2) G. Jayme and K. Rosenfeld, Changes in property of pulps by using ultrasonics. Das Papier 9 , 296-303 (1955) No. 13/14, Das Papier 9, 423-429 (1955) No. 17/18.

3) L. A. Gorbatschew, M. W. Ospischtschewa, J. W. Kosulin, N. W. Birbrower, L. I. Makowa, M. N. Wolmann, I. I. Sidorwa, Influence of hydrodynamic forces on the intensity of fibre stock treatment, Bumaschnaja Promyschleunost 3-4 (1976) No. 5.

4) J. Pav, M. Slabina, M. Soucec, Some results using generators of mechanical oscillations, WfP 93, 52-55 (165) No. 2.

5) W. H. Siewert, Dissertation Darmstadt 1966.

6) K. Rosenfeld and J. Hoffmann, A new process for refining at high consistencies above $20 \%$, Das Papier 19, 58-66 (165) No. 2.

7) A. P. Arlov, Beater performance as studied by means of fibre fractionation experiments, Norsk Skogindustrie 474-481 (1959) No. 12. Load elongation properties of paper sheets made from Bauer-McNett fractions of beaten sulphite pulp, Norsk Skogindustrie 342-350 (1959) No. 10.

8) R. Schmut, Fibre fractionation and paper properties, Southern Pulp and Paper Manufacturer $90 \mathrm{ft}$ (1959) No. 10.

9) E. Szwarcsztajn and K. Przybysz, Some aspects of pulp and waste paper fractionation, Das Papier 29, 295-300 (1975) No. 7. 